\title{
Airway wall thickness is increased in COPD patients with bronchodilator responsiveness
}

\author{
Victor Kim ${ }^{1 *}$, Parag Desai ${ }^{1}$, John D Newell $\mathrm{Jr}^{2}$, Barry J Make ${ }^{3}$, George R Washko ${ }^{4}$, Edwin K Silverman ${ }^{4}$, \\ James D Crapo ${ }^{3}$, Surya P Bhatt ${ }^{5}$, Gerard J Criner ${ }^{1}$ and the COPDGene Investigators
}

\begin{abstract}
Rationale: Bronchodilator responsiveness (BDR) is a common but variable phenomenon in COPD. The CT characteristics of airway dimensions that differentiate COPD subjects with BDR from those without BDR have not been well described. We aimed to assess airway dimensions in COPD subjects with and without BDR.

Methods: We analyzed subjects with GOLD 1-4 disease in the COPDGene ${ }^{\varpi}$ study who had CT airway analysis. We divided patients into two groups: $\mathrm{BDR}+$ (post bronchodilator $\Delta \mathrm{FEV}_{1} \geq 10 \%$ ) and BDR-(post bronchodilator $\Delta \mathrm{FEV} \mathrm{F}_{1}<10 \%$ ). The mean wall area percent (WA\%) of six segmental bronchi in each subject was quantified using VIDA. Using 3D SLICER, airway wall thickness was also expressed as the square root wall area of an airway of $10 \mathrm{~mm}$ (Pi10) and $15 \mathrm{~mm}$ (Pi15) diameter. \%Emphysema and \%gas trapping were also calculated.

Results: 2355 subjects in the BDR-group and 1306 in the BDR + group formed our analysis. The BDR + group had a greater Pi10, Pi15, and mean segmental WA\% compared to the BDR-group. In multivariate logistic regression using gender, race, current smoking, history of asthma, \%emphysema, \%gas trapping, \%predicted FEV ${ }_{1}$, and \%predicted FVC, airway wall measures remained independent predictors of BDR. Using a threshold change in $\mathrm{FEV}_{1} \geq 15 \%$ and $\mathrm{FEV}_{1} \geq$ $12 \%$ and $200 \mathrm{~mL}$ to divide patients into groups, the results were similar.

Conclusion: BDR in COPD is independently associated with $C T$ evidence of airway pathology. This study provides us with greater evidence of changes in lung structure that correlate with physiologic manifestations of airflow obstruction in COPD.
\end{abstract}

Keywords: Bronchodilator responsiveness, Airway wall thickness, Chronic obstructive pulmonary disease, Airflow obstruction

\section{Introduction}

COPD is classically associated with irreversible or poorly reversible airflow obstruction [1], which helps to distinguish it from asthma. However, the concept that asthma and COPD have a similar pathogenesis was initially described by Orie et al. in 1961 [2]. This concept, known as the "Dutch Hypothesis," sparked tremendous debate, with many researchers arguing that COPD and asthma are distinct entities [3,4]. Nevertheless, bronchodilator responsiveness (BDR) is present in $54-83 \%$ of COPD patients [5-7]. To complicate matters, this phenomenon in $\mathrm{COPD}$ is not a consistent one; BDR is present on some

\footnotetext{
* Correspondence: victor.kim@tuhs.temple.edu

${ }^{1}$ Temple University School of Medicine, 785 Parkinson Pavilion, 3401 North Broad Street, Philadelphia, PA 19140, USA

Full list of author information is available at the end of the article
}

occasions but not others during serial lung function testing of the same subject $[7,8]$. BDR may have significant clinical importance in COPD; some studies showed that BDR is associated with a faster rate of lung function decline $[9,10]$, mortality $[11,12]$, and the development of airflow obstruction [13], whereas others have not [14].

It is currently unclear why some patients with COPD demonstrate BDR. A crucial pathologic feature of COPD is airway inflammation, which results in epithelial remodeling, smooth muscle hypertrophy, subepithelial fibrosis, and mucous cell metaplasia [15]. Several investigators have correlated airway remodeling and degree of airflow obstruction in COPD [16-18]. Similarly, airway wall thickness on CT scan correlates with degree of airflow obstruction in several studies [19-21]. However, CT correlates of BDR in COPD have not been well described. 
Given that BDR is characteristic of asthma and that asthma airway pathology is dominated by smooth muscle hypertrophy, it is reasonable to hypothesize that COPD patients with BDR have a greater degree of airway smooth muscle mass, and therefore thicker airways on CT imaging. We analyzed the 3661 subjects with COPD with quantified airway measurements in the Genetic Epidemiology of COPD Study (COPDGene). We hypothesized that patients with BDR would have greater CT measures of airway pathology and less emphysema compared to those without BDR.

\section{Methods}

The Genetic Epidemiology of COPD (COPDGene) Study is a multicenter observational study to analyze genetic susceptibility for the development of COPD. This study was IRB approved at all institutions (Temple IRB \#11369). Inclusion and exclusion criteria were described previously [22]. Briefly, enrollees are African-American or nonHispanic Caucasian between the ages of 45 and 80 with at least a 10 pack-year smoking history. Exclusion criteria include pregnancy, history of other lung diseases except asthma, prior lobectomy or lung volume reduction, active cancer undergoing treatment, known or suspected lung cancer.

\section{Lung function testing and group assignment}

We included patients with GOLD 1 through 4 disease severity in our analysis as defined by an $\mathrm{FEV}_{1} / \mathrm{FVC}$ ratio < 70. Each subject underwent pre- and post-bronchodilator spirometry using an EasyOne ${ }^{\mathrm{mm}}$ spirometer (Zurich, Switzerland) before and after the administration of 2 puffs of albuterol with spacer device. Bronchodilators were held prior to spirometry in usual fashion. Predicted values were obtained using NHANES III data [23]. BDR was assessed as an $\mathrm{FEV}_{1} \%$ change after bronchodilator $\left[\left(\mathrm{FEV}_{1}\right.\right.$ postBD $-\mathrm{FEV}_{1}$ preBD $) / \mathrm{FEV}_{1}$ preBD $] \times 100.10 \%$ was used as a threshold of BDR. The patients were divided into two groups: $\mathrm{BDR}+$, defined as $\geq 10 \%$ change in $\mathrm{FEV}_{1}[\mathrm{BDR}+$ $(10 \%)]$, and BDR-, defined as $<10 \%$ change in $\mathrm{FEV}_{1}$ [BDR(10\%)]. Thresholds of $\geq 15 \%$ change and $\geq 12 \%$ and $200 \mathrm{~mL}$ in $\mathrm{FEV}_{1}$ (American Thoracic Society criteria for BDR) were also analyzed separately as dividing points between groups $[\mathrm{BDR}+(15 \%)$ and BDR-(15\%), BDR + (ATS) and BDR(ATS)].

\section{Computed tomography}

Volumetric CT acquisitions were obtained at full inspiration and at the end of normal expiration. Thin-slice collimation with slice thickness and intervals of $<1 \mathrm{~mm}$ was used to enhance spatial resolution. Quantitative image analysis to calculate lung volumes, percent emphysema, and percent gas-trapping was performed using 3D SLICER (http://www.slicer.org/). Percent emphysema was defined as the total percentage of both lungs with attenuation values $<-950$ Hounsfield units on inspiratory images, and percent gas trapping was defined as the total percentage of both lungs with attenuation values $<-856$ Hounsfield units on expiratory images. Total lung capacity and functional residual capacity were calculated based on inspiratory and expiratory CT images, respectively. Airway disease was quantified using VIDA Diagnostics Inc.'s PW workstation software (http://www.vidadiagnostics.com) as wall area percent (WA\%: (wall area/total bronchial area) $\times 100$ ) [9]. The mean WA\% was calculated as the average of six segmental bronchi in each subject. Using 3D SLICER, airway wall thickness was also expressed as the square root wall area of a $10 \mathrm{~mm}$ diameter airway (Pi10) and $15 \mathrm{~mm}$ diameter airway (Pi15) as previously described [21].

\section{Statistical analysis}

Analysis was performed using SPSS v21.0. Categorical variables were compared between groups using Chi squared test. Continuous variables were evaluated using 2-tailed unpaired $t$ test. Wilcoxon rank sum test was used for non-normally distributed data. A p value $<0.05$ was considered statistically significant. Pearson correlations were performed between the measures of airway wall thickness and percent change in $\mathrm{FEV}_{1}$. Multivariate logistic regressions were performed to assess the independent effects of airway dimensions on BDR, using the $10 \%, 15 \%$, and ATS dividing points in separate models with current smoking, history of asthma, \%emphysema, \%gas trapping, $\mathrm{FEV}_{1}$ \%predicted, and FVC \%predicted as covariates. $\mathrm{FEV}_{1} / \mathrm{FVC}$ ratio was excluded due to significant co-linearity with spirometric parameters. In addition, a multivariate linear regression was performed for SGRQ scores, mMRC dyspnea scores, total and severe exacerbations as outcomes of interest with lung function and BDR as covariates.

\section{Results}

There were 1306 subjects in the BDR + (10\%) group (35.7\% of total) and 2355 subjects in the BDR-(10\%) group. Baseline subject characteristics are summarized in Table 1. The BDR + (10\%) group was older, was less likely to be currently smoking, had a greater history of asthma, worse lung function, higher BODE indices, worse health related quality of life (SGRQ scores), greater dyspnea, and greater total and severe exacerbation frequency compared to the BDR-(10\%) group. There were no differences in gender, race, $\mathrm{BMI}$, or 6-min walk distance. Similarly, the BDR $+(15 \%)(n=798,21.8 \%$ of total) group had a greater smoking history, history of asthma, higher BODE indices, worse SGRQ scores, greater dyspnea, worse lung function, and greater total exacerbation history compared to the BDR-(15\%) group 
Table 1 Baseline characteristics

\begin{tabular}{|c|c|c|c|c|c|c|c|c|c|}
\hline & BDR-(10\%) & $\mathrm{BDR}+(10 \%)$ & & BDR-(15\%) & $\mathrm{BDR}+(15 \%)$ & & BDR-(ATS) & $\mathrm{BDR}+(\mathrm{ATS})$ & \\
\hline & $n=2355$ & $n=1306$ & $\mathrm{p}$ & $n=2863$ & $\mathrm{n}=798$ & $\mathrm{p}$ & $n=2385$ & $n=1276$ & $p$ \\
\hline Age at enrollment & $62.94 \pm 8.43$ & $63.55 \pm 8.78$ & .039 & $63.04 \pm 8.49$ & $63.58 \pm 8.83$ & .111 & $63.16 \pm 8.36$ & $63.15 \pm 8.93$ & .963 \\
\hline Gender (\% male) & 57.4 & 55.1 & .191 & 57.1 & 54.5 & .185 & 56.8 & 56.1 & .700 \\
\hline Race (\% Caucasian) & 79.1 & 79.9 & .569 & 79.4 & 79.2 & .905 & 79.6 & 78.9 & .638 \\
\hline BMI $\left(\mathrm{kg} / \mathrm{m}^{2}\right)$ & $27.71 \pm 5.90$ & $28.05 \pm 6.03$ & .094 & $27.74 \pm 5.93$ & $28.16 \pm 6.00$ & .073 & $27.71 \pm 5.95$ & $28.06 \pm 5.95$ & .090 \\
\hline Smoking History (pack yrs) & $51.72 \pm 27.08$ & $52.35 \pm 27.18$ & .502 & $51.38 \pm 26.74$ & $53.98 \pm 28.32$ & .017 & $52.05 \pm 27.07$ & $51.75 \pm 27.03$ & .748 \\
\hline Current Smoking (\%) & 45.0 & 39.5 & .001 & 43.8 & 40.4 & .082 & 43.6 & 42.1 & .401 \\
\hline Distance walked, ft & $1262.57 \pm 410.64$ & $1237.53 \pm 394.89$ & .077 & $1266.14 \pm 409.31$ & $1208.67 \pm 387.07$ & $<.0001$ & $1253.44 \pm 413.03$ & $1254.04 \pm 390.33$ & .966 \\
\hline History of Asthma (\%) & 21.3 & 27.6 & $<.0001$ & 21.9 & 29.6 & $<.0001$ & 22.2 & 26.2 & .017 \\
\hline BODE index & $2.25 \pm 2.12$ & $2.72 \pm 2.05$ & $<.0001$ & $2.28 \pm 2.10$ & $2.94 \pm 2.03$ & $<.0001$ & $2.35 \pm 2.13$ & $2.55 \pm 2.05$ & .007 \\
\hline SGRQ score & $34.49 \pm 22.77$ & $39.07 \pm 22.47$ & $<.0001$ & $34.79 \pm 22.87$ & $40.91 \pm 21.73$ & $<.0001$ & $35.22 \pm 22.78$ & $37.80 \pm 22.65$ & .001 \\
\hline mMRC dyspnea score & $1.80 \pm 1.47$ & $1.99 \pm 1.43$ & $<.0001$ & $1.80 \pm 1.47$ & $2.11 \pm 1.39$ & $<.0001$ & $1.82 \pm 1.46$ & $1.94 \pm 1.45$ & .022 \\
\hline FEV1\% pred & $60.25 \pm 23.51$ & $53.90 \pm 20.74$ & $<.0001$ & $59.82 \pm 23.23$ & $51.4 \pm 19.63$ & $<.0001$ & $58.95 \pm 23.24$ & $56.17 \pm 21.73$ & $<.0001$ \\
\hline FVC\% pred & $83.45 \pm 20.52$ & $80.88 \pm 19.59$ & $<.0001$ & $83.37 \pm 20.50$ & $79.52 \pm 18.91$ & $<.0001$ & $81.87 \pm 20.35$ & $83.77 \pm 19.94$ & .007 \\
\hline FEV1/FVC & $0.54 \pm 0.13$ & $0.50 \pm 0.13$ & $<.0001$ & $0.53 \pm 0.13$ & $0.49 \pm 0.13$ & $<.0001$ & $0.53 \pm 0.13$ & $0.50 \pm 0.13$ & $<.0001$ \\
\hline FEV1\% change & $1.74 \pm 6.46$ & $20.10 \pm 10.82$ & $<.0001$ & $3.60 \pm 7.13$ & $25.10 \pm 11.22$ & $<.0001$ & $2.86 \pm 7.50$ & $18.43 \pm 12.48$ & $<.0001$ \\
\hline FVC\% change & $2.94 \pm 9.21$ & $17.85 \pm 20.58$ & $<.0001$ & $4.40 \pm 9.85$ & $22.13 \pm 24.15$ & $<.0001$ & $1.43 \pm 7.13$ & $21.02 \pm 19.78$ & $<.0001$ \\
\hline Exacerbation Frequency & $0.59 \pm 1.12$ & $0.71 \pm 1.22$ & .002 & $0.61 \pm 1.14$ & $0.70 \pm 1.22$ & .047 & $0.61 \pm 1.14$ & $0.67 \pm 1.19$ & .146 \\
\hline Severe Exacerbations & 17.5 & 20.7 & .018 & 18.1 & 20.4 & .140 & 18.3 & 19.3 & .476 \\
\hline
\end{tabular}

Data presented as mean \pm SD. 
( $n=2863)$. However, unlike the differences between the $\mathrm{BDR}+(10 \%)$ and BDR-(10\%) groups, the BDR + (15\%) group had a lower 6-minute walk distance, and did not have a greater history of severe exacerbations (defined as an exacerbation requiring an emergency room visit or hospitalization) compared to the BDR-(15\%) group. Similar to the BDR $+(10 \%)$ and BDR $+(15 \%)$ groups, the $\mathrm{BDR}+(\mathrm{ATS})$ group $(\mathrm{n}=1276,34.9 \%$ total $)$ had worse lung function, higher SGRQ scores, BODE scores, and mMRC dyspnea scores, but there were no differences in total and severe exacerbations. In all groups, percent change in FVC was greater in the BDR + groups.

When a multivariate linear regression was performed for SGRQ scores, mMRC dyspnea scores, total and severe exacerbations as outcomes of interest with $\mathrm{FEV}_{1} \%$ predicted, FVC \%predicted, and BDR by either $10 \%$, $15 \%$, or ATS criteria as covariates, BDR was not a significant predictor for these outcomes. This indicates that the differences in dyspnea, health related quality of life, and exacerbations were more likely a consequence of the differences in lung function in the BDR + groups.

Quantitative CT measurements are summarized in Table 2 . The BDR + (10\%) group had slightly more \%emphysema, had more \%gas trapping, and a higher functional residual capacity compared to the BDR-(10\%) group. Total lung capacity was not different between groups. Pi10, Pi15, and WA\% were significantly greater in the $\mathrm{BDR}+(10 \%)$ group compared to the BDR- $(10 \%)$ group. The results were similar with the BDR $+(15 \%)$ and BDR-(15\%) groups, but the differences was slightly greater compared to the differences between the BDR + (10\%) and BDR-(10\%) groups. The BDR + (ATS) group had greater Pi10, Pi15, and WA\% compared to the BDR(ATS) group. In contrast to the other two groups, the $\mathrm{BDR}+(\mathrm{ATS})$ group had similar \%emphysema and a lower FRC compared to the BDR-(ATS) group.
Table 3 summarizes airway dimensions according to $\mathrm{BDR}+(10 \%)$ or BDR-(10\%) by GOLD stage. In each GOLD stage, Pi10, Pi15, and WA\% is greater in the $\mathrm{BDR}+(10 \%)$ group, with the exception of Pi10 in GOLD 3 subjects. This is depicted in Figure 1. The three variables for airway thickness were weakly related to percent change in $\mathrm{FEV}_{1}$ as a continuous variable. The correlation coefficients for Pi10, Pi15, and WA\% are 0.148, 0.145, and 0.167 , respectively, $\mathrm{p}<0.0001$ for all relationships. Figure 2 demonstrates the relationship between WA\% and BDR.

Table 4 summarizes the odds ratios and 95\% confidence intervals for the multivariate logistic regressions for the three measures of bronchodilator responsiveness (BDR $\geq 10 \%, \mathrm{BDR} \geq 15 \%, \mathrm{BDR}+$ by $\mathrm{ATS}$ criteria) as the outcomes of interest with using the three measures of airway wall thickness as predictors of interest in separate models. All three measures of airway wall measures had significant odds ratios for bronchodilator responsiveness. The most significant odds ratios were for Pi15 (4.60 [95\% CI 3.13, 6.75], 5.35 [95\% CI 3.48, 8.24], and 5.13 [95\% CI 3.46, 7.61] for BDR + (10\%), (15\%), and (ATS), respectively). Asthma history was not a significant predictor of BDR in these multivariate models (1.07 [95\% CI 0.99, 1.15], 0.99 [95\% CI 0.91, 1.08], and 0.97 [95\% CI 0.81, 1.16] for BDR + (10\%), (15\%), and (ATS), respectively).

\section{Discussion}

We have demonstrated that subjects with BDR have CT evidence of thicker airways than non BDR subjects using three different thresholds for change in $\mathrm{FEV}_{1}$. We also showed that the two groups divided by changes in $\mathrm{FEV}_{1}$ were similar in terms of race and gender distribution, but had higher BODE indices, worse lung function, worse health related quality of life and dyspnea, and greater exacerbation frequency. To our knowledge, this

Table 2 Quantitative CT measurements

\begin{tabular}{|c|c|c|c|c|c|c|c|c|c|}
\hline & BDR-(10\%) & $\mathrm{BDR}+(10 \%)$ & & BDR-(15\%) & $\mathrm{BDR}+(15 \%)$ & & BDR-(ATS) & BDR + (ATS) & \\
\hline & $n=2355$ & $n=1306$ & $\mathbf{p}$ & $n=2863$ & $n=798$ & $p$ & $n=2385$ & $n=1276$ & $p$ \\
\hline \%emphysema & $11.36 \pm 12.34$ & $12.22 \pm 11.96$ & .042 & $11.43 \pm 12.23$ & $12.53 \pm 12.12$ & .024 & $11.78 \pm 12.77$ & $11.45 \pm 11.96$ & .431 \\
\hline \%gas trapping & $33.96 \pm 20.93$ & $39.04 \pm 20.22$ & $<.0001$ & $34.46 \pm 20.85$ & $40.48 \pm 20.00$ & $<.0001$ & $34.93 \pm 20.88$ & $37.36 \pm 20.61$ & .001 \\
\hline $\mathrm{TLC}$ & $6.01 \pm 1.43$ & $6.09 \pm 1.47$ & .090 & $6.01 \pm 1.44$ & $6.11 \pm 1.48$ & .095 & $5.96 \pm 1.44$ & $6.31 \pm 1.44$ & .134 \\
\hline FRC & $3.78 \pm 1.2$ & $4.05 \pm 1.24$ & $<.0001$ & $3.80 \pm 1.20$ & $4.15 \pm 1.25$ & $<.0001$ & $3.87 \pm 1.25$ & $3.89 \pm 1.10$ & $<.0001$ \\
\hline $\begin{array}{l}\text { TLC \%pred, } \\
\text { race-adjusted }\end{array}$ & $101.15 \pm 16.52$ & $103.65 \pm 16.42$ & $<.0001$ & $101.34 \pm 16.49$ & $104.56 \pm 16.44$ & $<.0001$ & $101.56 \pm 16.41$ & $102.94 \pm 16.70$ & .016 \\
\hline $\begin{array}{l}\text { FRC \%pred, } \\
\text { race-adjusted }\end{array}$ & $117.90 \pm 31.85$ & $127.02 \pm 31.12$ & $<.0001$ & $118.62 \pm 31.69$ & $130.25 \pm 30.95$ & $<.0001$ & $118.86 \pm 31.55$ & $125.43 \pm 32.10$ & $<.0001$ \\
\hline Pi10 & $3.69 \pm 0.14$ & $3.73 \pm 0.15$ & $<.0001$ & $3.69 \pm 0.14$ & $3.74 \pm 0.15$ & $<.0001$ & $3.69 \pm 0.14$ & $3.72 \pm 0.15$ & $<.0001$ \\
\hline Pi15 & $5.17 \pm 0.2$ & $5.24 \pm 0.21$ & $<.0001$ & $5.18 \pm 0.20$ & $5.26 \pm 0.21$ & $<.0001$ & $5.17 \pm 0.20$ & $5.24 \pm 0.21$ & $<.0001$ \\
\hline $\begin{array}{l}\text { Wall area \%, } \\
\text { segmental }\end{array}$ & $61.97 \pm 3.15$ & $63.12 \pm 2.94$ & $<.0001$ & $62.08 \pm 3.12$ & $63.45 \pm 2.89$ & $<.0001$ & $62.07 \pm 3.14$ & $62.97 \pm 3.00$ & $<.0001$ \\
\hline
\end{tabular}


Table 3 Airway dimensions by GOLD stage

\begin{tabular}{lllll}
\hline GOLD & Variable & BDR-(10\%) & BDR + (10\%) & p \\
\hline 1 & & $n=519$ & $n=143$ & \\
& Pi10 & $3.62 \pm 0.10$ & $3.64 \pm 0.12$ & .016 \\
& Pi15 & $5.08 \pm 0.15$ & $5.14 \pm 0.19$ & $<.0001$ \\
& WA\%, Seg & $60.04 \pm 2.66$ & $61.32 \pm 2.99$ & $<.0001$ \\
& & $n=1029$ & $n=564$ & \\
& Pi10 & $3.68 \pm 0.12$ & $3.71 \pm 0.15$ & $<.0001$ \\
& Pi15 & $5.19 \pm 0.21$ & $5.23 \pm 0.21$ & $<.0001$ \\
& WA\%, Seg & $62.06 \pm 3.01$ & $62.90 \pm 2.90$ & $<.0001$ \\
& & $n=501$ & $n=425$ & \\
& Pi10 & $3.74 \pm 0.14$ & $3.75 \pm 0.15$ & .289 \\
& Pi15 & $5.22 \pm 0.22$ & $5.27 \pm 0.21$ & .001 \\
& WA\%, Seg & $63.04 \pm 3.02$ & $63.64 \pm 2.81$ & .002 \\
& & $n=506$ & $n=174$ & \\
& Pi10 & $3.75 \pm 0.14$ & $3.78 \pm 0.13$ & .031 \\
& Pi15 & $5.19 \pm 0.20$ & $5.24 \pm 0.21$ & .004 \\
& WA\%, Seg & $63.20 \pm 3.01$ & $64.02 \pm 2.60$ & .003 \\
\hline
\end{tabular}

is the most comprehensive clinical and CT description of subjects with and without BDR.

We chose $\mathrm{FEV}_{1}$ to determine BDR using several cutoff values based on prior studies $[24,25]$ because of the notion that changes in $\mathrm{FEV}_{1}$ may be more reflective of airway disease. In addition to percent changes, we also analyzed an absolute change in $\mathrm{FEV}_{1}$ to divide subjects into groups. Indeed, many patients with COPD, particularly those with worse disease, demonstrate responsiveness to bronchodilator by an increase in FVC as opposed to $\mathrm{FEV}_{1}$ [26]. This may represent decreases in air trapping and dynamic airway collapse during forced expiratory maneuvers [27]. In our study, we found that those with BDR by $\mathrm{FEV}_{1}$ criteria also had significantly greater increases in FVC, and thus could also be labeled "volume responders" in addition to "flow responders" [14].

Studies have shown conflicting results in clinical outcomes of BDR in COPD. There are some studies that show an accelerated decline in lung function in reversible patients, whereas other studies have not $[9,14,28]$. In the Evaluation of COPD Longitudinally to Identify Predictive Surrogate Endpoints (ECLIPSE), a three year prospective observational study, patients with BDR had a $17 \pm 4 \mathrm{ml}$ per year greater rate of decline in $\mathrm{FEV}_{1}$ compared to those without BDR [9], but no differences in mortality, hospitalizations, or exacerbations were found [29]. Bronchial hyper-responsiveness was found to accelerate lung function decline in over 7,000 individuals and conferred an odds ratio of 4.5 for the development of COPD [13]. However, Nishimura et al. categorized GOLD 1-4. COPD patients into rapid decliners, slow decliners, and sustainers of lung function and found no

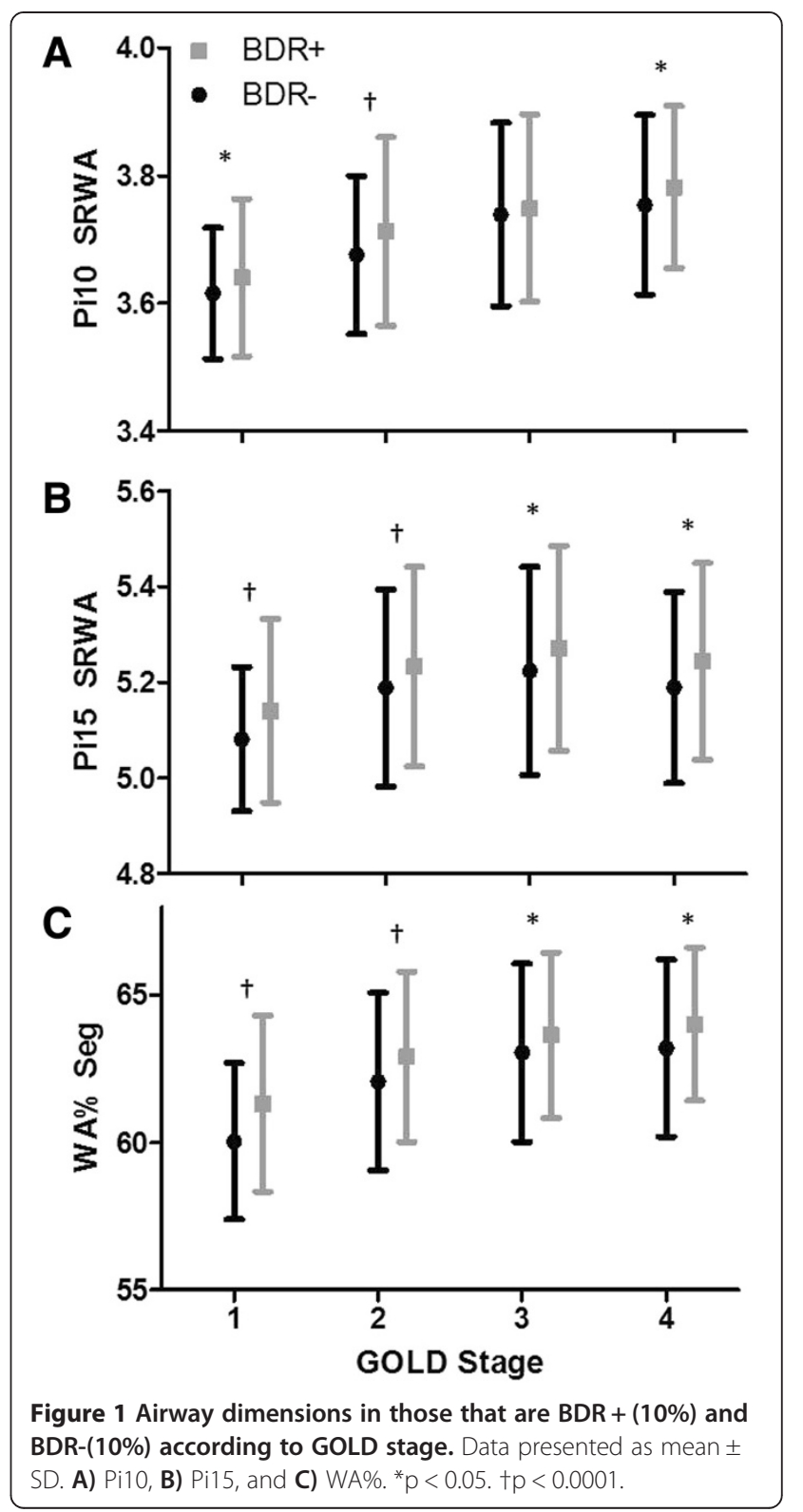

difference in the presence of BDR among these three groups [14]. Similarly, there was no relationship between $\mathrm{BDR}$ and rate of lung function decline in the Inhaled Steroids in Obstructive Lung Disease in Europe trial (ISOLDE) or the Understanding Potential Long-term Improvements in Function with Tiotropium trial (UPLIFT) $[24,28]$. In addition, acute bronchodilator responsiveness did not predict improvements in lung function with tiotropium [24]. Therefore, it is unclear if BDR in COPD has any clinical significance.

Part of the problem lies in the variability in the definition of BDR across studies and the inconsistency of BDR in COPD subjects over time. Calverley et al. found that $52 \%$ of 660 patients with serial lung function testing switched responder status to bronchodilator [8]. In the 


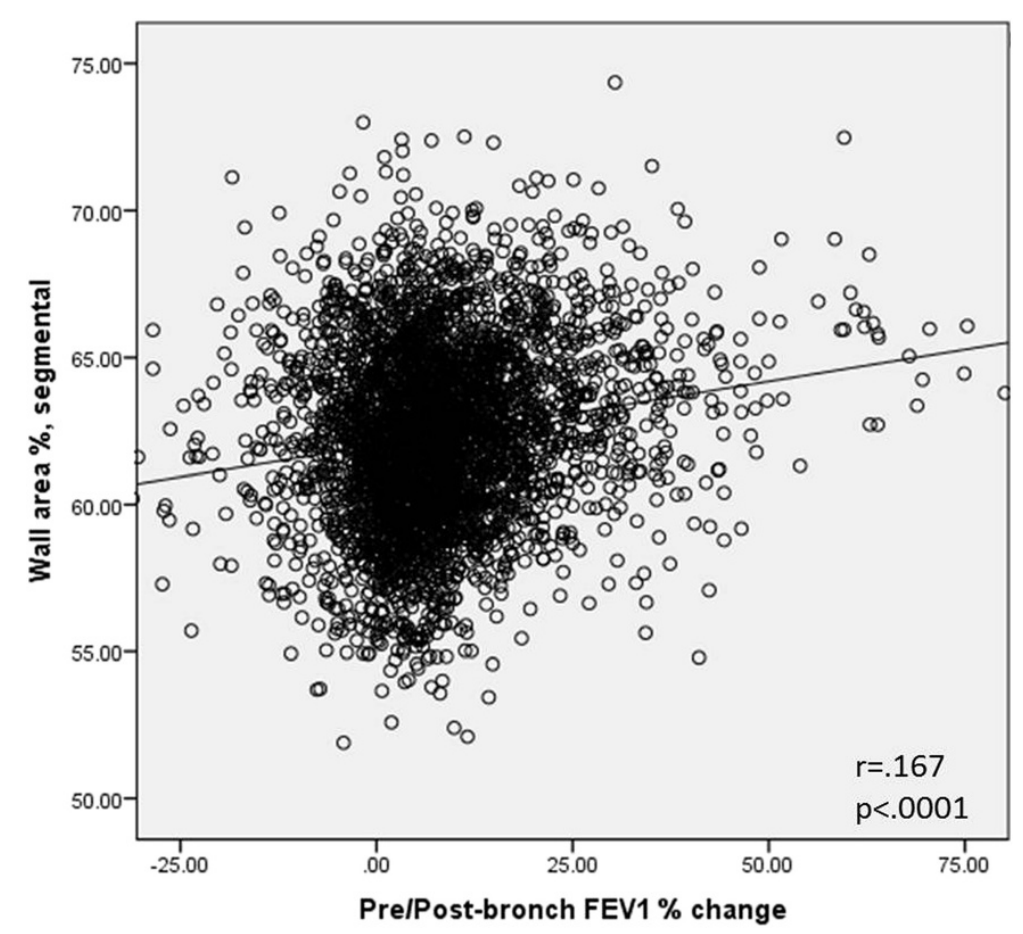

Figure 2 Relationship between WA\% and percent change in $\mathrm{FEV}_{1}$.

National Intermittent Positive Pressure Breathing Trial, $65 \%$ of patients had at least 1 visit with $15 \%$ improvement in lung function with administration of isoproterenol over a period of 2 years [30]. Another complicating matter is that using American Thoracic Society criteria of a change in $\mathrm{FEV}_{1}$ of $12 \%$ and $200 \mathrm{cc}$ may be too restrictive for subjects with very severe airflow obstruction [31]. For someone with an $\mathrm{FEV}_{1}$ of $800 \mathrm{cc}$, for example, a change of 200 cc would translate into a change of $25 \%$, a change much greater than $12 \%$. In addition, many patients with severe COPD demonstrate a change in FVC acutely, not necessarily $\mathrm{FEV}_{1}$, in response to bronchodilator [26]. Thus, a practical, consistent definition of BDR is needed in order to understand the importance of this physiologic phenomenon.

Regardless of its clinical consequences, BDR is associated with thicker airways based on quantitative CT imaging. The reason for these observed differences is not clear, but our results are hypothesis generating. It is possible that genetic influences have bearing on BDR in
COPD, accounting for both the physiologic and CT differences between those with and without BDR. Indeed, one study revealed greater BDR in smokers of first degree relatives with early onset COPD [32], and another identified several genomic regions that could contain loci regulating BDR [33]. If that is the case, then this could mean there are different potential therapeutic targets for those with BDR. This would have to be confirmed with more extensive genetic analysis. In addition, we have shown that advanced emphysema patients with greater airway smooth muscle mass were more likely to demonstrate BDR on lung function testing [34]. Other investigators have found direct correlations with the degree of smooth muscle mass and airflow obstruction in COPD $[16,17]$. The increased CT airway thickness in the BDR groups may represent a greater degree of smooth muscle hypertrophy, which is thought to be the pathologic correlate in asthma responsible for bronchodilator responsiveness and airway hyper-responsiveness. These findings, however, must be confirmed in studies that also

Table 4 Multivariate logistic regression for bronchodilator reversibility

\begin{tabular}{|c|c|c|c|c|c|c|c|c|c|}
\hline \multirow[b]{3}{*}{ Pi10 } & \multicolumn{3}{|c|}{ BDR + (10\%) } & \multicolumn{3}{|c|}{ BDR + (15\%) } & \multicolumn{3}{|c|}{ BDR + (ATS) } \\
\hline & \multirow{2}{*}{$\begin{array}{l}\text { OR } \\
4.59\end{array}$} & \multicolumn{2}{|c|}{$95 \% \mathrm{Cl}$} & \multirow{2}{*}{$\begin{array}{l}\text { OR } \\
6.27\end{array}$} & \multicolumn{2}{|c|}{$95 \% \mathrm{Cl}$} & \multirow{2}{*}{$\begin{array}{l}\text { OR } \\
5.82\end{array}$} & \multicolumn{2}{|c|}{$95 \% \mathrm{Cl}$} \\
\hline & & 2.62 & 8.06 & & 3.33 & 11.79 & & 3.30 & 10.24 \\
\hline Pi15 & 4.60 & 3.13 & 6.75 & 5.35 & 3.48 & 8.24 & 5.13 & 3.46 & 7.61 \\
\hline WA\% Segmental & 1.11 & 1.08 & 1.14 & 1.12 & 1.09 & 1.16 & 1.10 & 1.07 & 1.13 \\
\hline
\end{tabular}

Using each variable in lefthand column in a separate model with gender, race, current smoking, history of asthma, \%emphysema, \%gas trapping, FEV ${ }_{1} \%$ pred, and FVC \%pred as covariates. $\mathrm{P}<0.001$ for all odds ratios. 
obtain surgical lung tissue or autopsy obtained tissue to confirm our results pathologically. Finally, it has been proposed that gas trapping may be a surrogate marker for airway disease in COPD; the association between BDR and gas trapping in our cohort is consistent with this notion.

Of interest was the finding that percent emphysema and percent gas trapping were greater in those in the $\mathrm{BDR}+(10 \%)$ and BDR $+(15 \%)$ groups, but there was no difference in emphysema in the BDR + (ATS) group. This most likely reflects the differences in lung function between the groups; $\mathrm{FEV}_{1}$ and $\mathrm{FVC}$ \%predicted were lower in the BDR + (10\%) and BDR + (15\%) groups and higher in the BDR + (ATS) group. This phenomenon likely is a result of greater ease in achieving an absolute change of $200 \mathrm{~mL}$ with bronchodilator in those with better lung function. In addition, in the multivariate models for BDR + presented in Table 4, \%emphysema had slightly but significantly reduced odds ratios for BDR, and \%gas trapping had slightly but significantly greater odds ratios for BDR. This is consistent with prior studies that have found lower percent emphysema is associated with BDR [35].

This study has some noteworthy limitations. Firstly, lung function testing was only performed once, leading to the possibility of inconsistency and lack of repeatability of the response to bronchodilator during serial testing. Some subjects that were not reversible may demonstrate reversibility on their next measure of airflow by spirometry [8]. Secondly, outcomes such as exacerbation and asthma history were by subject self-report, lending to recall bias. In addition, the inclusion of subjects with asthma, whether or not the diagnosis was made by a physician, is a limitation of the study. Thirdly, the differences in airway measurements were small between groups, making the significance of the data questionable. However, the multivariate analyses clearly show BDR, using various definitions, to increase the odds of having thicker airways. Finally, many of the clinical phenotypic differences are most likely the result of differences in lung function between the two groups.

\section{Conclusions}

We show that quantitative CT measures of airway thickness are greater in those with bronchodilator responsiveness. This is one more step towards bridging the gap between radiological and pathological correlations. How these differences in airway thickness translates to airway pathology remains to be determined.

\section{Abbreviations}

BDR: Bronchodilator responsiveness; BDR + (10\%): Bronchodilator responsiveness as defined by increase in $\mathrm{FEV}_{1}$ by $10 \% ; \mathrm{BDR}+(15 \%)$ : Bronchodilator responsiveness as defined by increase in $\mathrm{FEV}_{1}$ by $15 \%$; $\mathrm{BDR}+(\mathrm{ATS})$ : Bronchodilator responsiveness as defined by increase in $\mathrm{FEV}_{1}$ by $12 \%$ and 200 mL; BODE: Body mass index, airflow obstruction, dyspnea, exercise capacity; COPD: Chronic obstructive pulmonary disease; $\mathrm{CT}$ : Computed tomography;
$\mathrm{FEV}_{1}$ : Forced expiratory volume in 1 second; FRC: Functional residual capacity; FVC: Forced vital capacity; mMRC: Modified Medical Research Council; Pi10: Airway of $10 \mathrm{~mm}$ internal perimeter; Pi15: Airway of $15 \mathrm{~mm}$ internal perimeter; SGRQ: St. George's Respiratory Questionaire; TLC: Total lung capacity; WA\%: Wall area percent.

\section{Competing interests}

The authors declare no competing interests.

\section{Authors' contributions}

VK, PD, GJC were involved in the conception, hypotheses delineation, and design of the study and acquisition of the data; VK, PD, GW, JDN, and GJC were involved in the analysis and interpretation of the data; VK, PD, GJC, SB, GW, BJM, JC, EKS were involved in the writing the article or substantial involvement in its revision prior to submission. VK is the guarantor of the content of the manuscript. All authors read and approved the final manuscript.

\section{Acknowledgements}

We acknowledge and thank the COPDGene Core Teams:

Administrative Core: James D. Crapo, MD (PI); Edwin K. Silverman, MD, PhD (PI); Barry J. Make, MD; Elizabeth A. Regan, MD, PhD; Stephanie Bratschie, MPH; Rochelle Lantz; Sandra Melanson, MSW, LCSW; Lori Stepp Executive Committee: Terri Beaty, PhD; Russell P. Bowler, MD, PhD; James D. Crapo, MD; Jeffrey L. Curtis, MD; Douglas Everett, PhD; MeiLan K. Han, MD, MS; John E. Hokanson, MPH, PhD; David Lynch, MB; Barry J. Make, MD; Elizabeth A. Regan, MD, PhD; Edwin K. Silverman, MD, PhD; E. Rand Sutherland, MD External Advisory Committee: Eugene R. Bleecker, MD; Harvey O. Coxson, PhD; Ronald G. Crystal, MD; James C. Hogg, MD; Michael A. Province, PhD; Stephen I. Rennard, MD; Duncan C. Thomas, PhD

NHLBI: Thomas Croxton, MD, PhD; Weiniu Gan, PhD; Lisa Postow, PhD COPD Foundation: John W. Walsh; Randel Plant; Delia Prieto

Data Coordinating Center: Douglas Everett, PhD; Andre Williams, PhD; Ruthie Knowles; Carla Wilson, MS

Epidemiology Core: John Hokanson, MPH, PhD; Jennifer Black-Shinn, MPH; Gregory Kinney, MPH

Genetic Analysis Core: Terri Beaty, PhD; Peter J. Castaldi, MD, MSc; Michael Cho, MD; Dawn L. DeMeo, MD, MPH; Marilyn G. Foreman, MD, MS; Nadia N. Hansel, MD, MPH; Megan E. Hardin, MD; Craig Hersh, MD, MPH; Jacqueline Hetmanski, MS; John E. Hokanson, MPH, PhD; Nan Laird, PhD; Christoph Lange, PhD; Sharon M. Lutz, MPH, PhD; Manuel Mattheisen, MD; Merry-Lynn McDonald, MSc, PhD; Margaret M. Parker, MHS; Elizabeth A. Regan, MD, PhD; Stephanie Santorico, PhD; Edwin K. Silverman, MD, PhD; Emily S. Wan, MD; Jin Zhou, PhD

Genotyping Cores: Genome-Wide Core: Terri Beaty, PhD; Candidate Genotyping Core: Craig P. Hersh, MD, MPH; Edwin K. Silverman, MD, PhD

Imaging Core: David Lynch, MB; Mustafa Al Qaisi, MD; Jaleh Akhavan; Christian W. Cox, MD; Harvey O. Coxson, PhD; Deanna Cusick; Jennifer G. Dy, PhD; Shoshana Ginsburg, MS; Eric A. Hoffman, PhD; Philip F. Judy, PhD; Alex Kluiber; Alexander McKenzie; John D. Newell, Jr., MD; John J. Reilly, Jr., MD; James Ross, MSc; Raul San Jose Estepar, PhD; Joyce D. Schroeder, MD; Jered Sieren; Arkadiusz Sitek, PhD; Douglas Stinson; Edwin van Beek, MD, PhD, MEd; George R. Washko, MD; Jordan Zach

PFT QA Core: Robert Jensen, PhD; E. Rand Sutherland, MD Biological Repository, Johns Hopkins University, Baltimore, MD: Homayoon Farzadegan, PhD: Samantha Bragan; Stacey Cayetano

We further wish to acknowledge the COPDGene Investigators from the participating Clinical Centers:

Ann Arbor VA: Jeffrey Curtis, MD, Ella Kazerooni, MD

Baylor College of Medicine, Houston, TX: Nicola Hanania, MD, MS, Philip Alapat, MD, Venkata Bandi, MD, Kalpalatha Guntupalli, MD, Elizabeth Guy, MD, Antara Mallampalli, MD, Charles Trinh, MD, Mustafa Atik, MD, Hasan Al-Azzawi, MD, Marc Willis, DO, Susan Pinero, MD, Linda Fahr, MD, Arun Nachiappan, MD, Collin Bray, MD, L. Alexander Frigini, MD, Carlos Farinas, MD, David Katz, MD, Jose Freytes, MD, Anne Marie Marciel, MD Brigham and Women's Hospital, Boston, MA: Dawn DeMeo, MD, MPH, Craig Hersh, MD, MPH, George Washko, MD, Francine Jacobson, MD, MPH, Hiroto Hatabu, MD, PhD, Peter Clarke, MD, Ritu Gill, MD, Andetta Hunsaker, MD, Beatrice Trotman-Dickenson, MBBS, Rachna Madan, MD Columbia University, New York, NY: R. Graham Barr, MD, DrPH, Byron Thomashow, MD, John Austin, MD, Belinda D'Souza, MD 
Duke University Medical Center, Durham, NC: Neil Maclntyre, Jr., MD, Lacey Washington, MD, H Page McAdams, MD

Richard Rosiello, MD, Timothy Bresnahan, MD, Joseph Bradley, MD, Sharon Kuong, MD, Steven Meller, MD, Suzanne Roland, MD

Health Partners Research Foundation, Minneapolis, MN: Charlene McEvoy, MD, MPH, Joseph Tashjian, MD

Johns Hopkins University, Baltimore, MD: Robert Wise, MD, Nadia Hansel, MD, MPH, Robert Brown, MD, Gregory Diette, MD, Karen Horton, MD

Los Angeles Biomedical Research Institute at Harbor UCLA Medical Center, Los Angeles, CA: Richard Casaburi, MD, Janos Porszasz, MD, PhD, Hans Fischer, MD, PhD, Matt Budoff, MD, Mehdi Rambod, MD

Michael E. DeBakey VAMC, Houston, TX: Amir Sharafkhaneh, MD, Charles Trinh, MD, Hirani Kamal, MD, Roham Darvishi, MD, Marc Willis, DO, Susan Pinero, MD, Linda Fahr, MD, Arun Nachiappan, MD, Collin Bray, MD, L. Alexander Frigini, MD, Carlos Farinas, MD, David Katz, MD, Jose Freytes, MD, Anne Marie Marciel, MD Minneapolis VA: Dennis Niewoehner, MD, Quentin Anderson, MD, Kathryn Rice, MD, Audrey Caine, MD

Morehouse School of Medicine, Atlanta, GA: Marilyn Foreman, MD, MS, Gloria Westney, MD, MS, Eugene Berkowitz, MD, PhD

National Jewish Health, Denver, CO: Russell Bowler, MD, PhD, David Lynch, $M B$, Joyce Schroeder, MD, Valerie Hale, MD, John Armstrong, II, MD, Debra Dyer, MD, Jonathan Chung, MD, Christian Cox, MD

Temple University, Philadelphia, PA: Gerard Criner, MD, Victor Kim, MD, Nathaniel Marchetti, DO, Aditi Satti, MD, A. James Mamary, MD, Robert Steiner, MD, Chandra Dass, MD, Libby Cone, MD

University of Alabama, Birmingham, AL: William Bailey, MD, Mark Dransfield, MD, Michael Wells, MD, Surya Bhatt, MD, Hrudaya Nath, MD, Satinder Singh, MD University of California, San Diego, CA: Joe Ramsdell, MD, Paul Friedman, MD University of lowa, lowa City, IA: Alejandro Cornellas, MD, John Newell, Jr., $M D$, Edwin JR van Beek, MD, PhD

University of Michigan, Ann Arbor, Ml: Fernando Martinez, MD, MeiLan Han, $\mathrm{MD}$, Ella Kazerooni, MD

University of Minnesota, Minneapolis, MN: Christine Wendt, MD, Tadashi Allen, MD University of Pittsburgh, Pittsburgh, PA: Frank Sciurba, MD, Joel Weissfeld, MD, MPH, Carl Fuhrman, MD, Jessica Bon, MD, Danielle Hooper, MD University of Texas Health Science Center at San Antonio, San Antonio, TX: Antonio Anzueto, MD, Sandra Adams, MD, Carlos Orozco, MD, Mario Ruiz, MD, Amy Mumbower, MD, Ariel Kruger, MD, Carlos Restrepo, MD, Michael Lane, MD COPDGene is supported by NHLBI R01 HL089856 and R01 HL089897

\section{Disclosures}

VK has nothing to disclose in relationship to this manuscript but has served on an advisory committee for CSA and has participated in clinical trials sponsored by Boehringer Ingelheim, Glaxo-Smith-Kline, and Roche pharmaceuticals. VK is supported by NHLBI K23HL094696. JDN is a paid consultant for VIDA Diagnostics Inc and has stock options in VIDA Diagnostics Inc. JDN has funded research from Siemens Health. EKS received grant support and consulting fees from GlaxoSmithKline for studies of COPD genetics. EKS received grant support from GlaxoSmithKline for studies of COPD genetics, and he received honoraria and consulting fees from AstraZeneca, Merck, and GlaxoSmithKline. PD, SPB, and JC have nothing to disclose. GW has received grants from the NHLBI to perform quantitative image analysis and have been a paid consultant for Medlmmune and Spiration, and his spouse is an employee of Merck Research Laboratories. Over the last three years, BJM has participated in advisory boards, speaker bureaus, consultations and multi-center clinical trials with funding from the National Heart Lung and Blood Institute, Abbott, Astellas, AstraZeneca, Boerhinger-Ingelheim, Coviden, Dey, Forest, GlaxoSmithKline, Merck, Medlmmune, NABI, Novartis, Pfizer, Respironics, Sepracor, Sequal and Talecris. GJC has served on Advisory Committees for Boehringer Ingelheim, Ikaria, Holaira, CSA and Amirall. All of these sums are less than $\$ 2,500$. GJC has received research grants from: Boehringer Ingelheim, Forest, Actelion, Glaxo-Smith-Kline, AstraZeneca, Pearl, Novartis Pharmaceuticals, Pulmonx, PneumRX and Aeris Therapeutics. All research grant monies are deposited and controlled by Temple University.

\section{Author details}

${ }^{1}$ Temple University School of Medicine, 785 Parkinson Pavilion, 3401 North Broad Street, Philadelphia, PA 19140, USA. ${ }^{2}$ University of lowa Hospital and Clinics, lowa City, IA, USA. ${ }^{3}$ National Jewish Health, Denver, CO, USA. ${ }^{4}$ Brigham and Women's Hospital, Boston, MA, USA. ${ }^{5}$ University of Alabama, Birmingham, $A B, U S A$.
Received: 29 May 2014 Accepted: 20 July 2014

Published: 8 August 2014

\section{References}

1. Global Initiative for Chronic Obstructive Pulmonary Disease: Global strategy for the diagnosis, management and prevention of chronic obstructive pulmonary disease, executive summary 2005. 2005, www.goldcopd.com.

2. Orie NG: The dutch hypothesis. Chest 2000, 117(5 Suppl 1):299S.

3. Barnes PJ: Mechanisms in COPD: differences from asthma. Chest 2000, 117(2 Suppl):10S-14S.

4. Vermeire PA, Pride NB: A "splitting" look at chronic nonspecific lung disease (CNSLD): common features but diverse pathogenesis. Eur Respir J 1991, 4(4):490-496.

5. Dorinsky PM, Reisner C, Ferguson GT, Menjoge SS, Serby CW, Witek TJ Jr: The combination of ipratropium and albuterol optimizes pulmonary function reversibility testing in patients with COPD. Chest 1999, 115(4):966-971.

6. Mahler DA, Wire P, Horstman D, Chang CN, Yates J, Fischer T, Dorinsky PM, Reisner C, Ferguson GT, Menjoge SS, Serby CW, Witek TJ Jr: Effectiveness of fluticasone propionate and salmeterol combination delivered via the diskus device in the treatment of chronic obstructive pulmonary disease. Am J Respir Crit Care Med 2002, 166(8):1084-1091.

7. Tashkin DP, Celli B, Senn S, Burkhart D, Kesten S, Menjoge S, Decramer D, for the UPLIFT Study Investigators: A 4-year trial of tiotropium in chronic obstructive pulmonary disease. N Engl J Med 2008, 359(15):1543-1554.

8. Calverley PM, Burge PS, Spencer S, Anderson JA, Jones PW: Bronchodilator reversibility testing in chronic obstructive pulmonary disease. Thorax 2003, 58(8):659-664.

9. Vestbo J, Edwards LD, Scanlon PD, Yates JC, Agusti A, Bakke P, Calverley PM, Celli B, Coxson HO, Crim C, Lomas DA, Macnee W, Miller BE, Silverman EK, Tal-Singer R, Wouters E, Rennard SI, Eclipse Investigators: Changes in forced expiratory volume in 1 second over time in COPD. N Engl I Med 2011, 365(13):1184-1192.

10. Vollmer WM, Johnson LR, Buist AS: Relationship of response to a bronchodilator and decline in forced expiratory volume in one second in population studies. Am Rev Respir Dis 1985, 132(6):1186-1193.

11. Postma DS, Gimeno F, van der Weele LT, Sluiter HJ: Assessment of ventilatory variables in survival prediction of patients with chronic airflow obstruction: the importance of reversibility. Eur J Respir Dis 1985, 67(5):360-368.

12. Postma DS, De Vries K, Koeter GH, Sluiter HJ: Independent influence of reversibility of air-flow obstruction and nonspecific hyperreactivity on the long-term course of lung function in chronic air-flow obstruction. Am Rev Respir Dis 1986, 134(2):276-280.

13. Brutsche MH, Downs SH, Schindler C, Gerbase MW, Schwartz J, Frey M, Russi EW, Ackermann-Liebrich U, Leuenberger P, SAPALDIA Team: Bronchial hyperresponsiveness and the development of asthma and COPD in asymptomatic individuals: SAPALDIA cohort study. Thorax 2006, 61(8):671-677.

14. Nishimura M, Makita H, Nagai K, Konno S, Nasuhara Y, Hasegawa M, Shimizu K, Betsuyaku T, Ito YM, Fuke S, Igarashi T, Akiyama Y, Ogura S, Hokkaido COPD Cohort Study Investigators: Annual change in pulmonary function and clinical phenotype in chronic obstructive pulmonary disease. Am J Respir Crit Care Med 2012, 185(1):44-52.

15. Kim V, Rogers TJ, Criner GJ: New concepts in the pathobiology of chronic obstructive pulmonary disease. Proc Am Thorac Soc 2008, 5(4):478-485.

16. Finkelstein R, Fraser RS, Ghezzo H, Cosio MG: Alveolar inflammation and its relation to emphysema in smokers. Am J Respir Crit Care Med 1995, 152(5 Pt 1):1666-1672.

17. Hogg JC, Chu F, Utokaparch S, Woods R, Elliott WM, Buzatu L, Cherniack RM, Rogers RM, Sciurba FC, Coxson HO, Pare PD: The nature of small-airway obstruction in chronic obstructive pulmonary disease. N Engl J Med 2004, 350(26):2645-2653.

18. Kim V, Kelemen SE, Abuel-Haija M, Gaughan J, Sharafkhaneh A, Evans CM, Dickey BF, Solomides CC, Rogers TJ, Criner GJ: Small airway mucous metaplasia and inflammation in chronic obstructive pulmonary disease. J COPD 2008, 5(6):329-338.

19. Nakano Y, Muro S, Sakai H, Hirai T, Chin K, Tsukino M, Nishimura K, Itoh H, Pare PD, Hogg JC, Mishima M: Computed tomographic measurements of airway dimensions and emphysema in smokers. correlation with lung function. Am J Respir Crit Care Med 2000, 162(3 Pt 1):1102-1108. 
20. Hasegawa M, Nasuhara $Y$, Onodera $Y$, Makita H, Nagai K, Fuke S, Ito $Y$, Betsuyaku T, Nishimura M: Airflow limitation and airway dimensions in chronic obstructive pulmonary disease. Am J Respir Crit Care Med 2006 173(12):1309-1315.

21. Patel BD, Coxson HO, Pillai SG, Agusti AG, Calverley PM, Donner CF, Make BJ, Muller NL, Rennard SI, Vestbo J, Wouters EF, Hiorns MP, Nakano Y, Camp PG, Nasute Fauerbach PV, Screaton NJ, Campbell EJ, Anderson WH, Pare PD, Levy RD, Lake SL, Silverman EK, Lomas DA, International COPD Genetics Network: Airway wall thickening and emphysema show independent familial aggregation in chronic obstructive pulmonary disease. Am J Respir Crit Care Med 2008, 178(5):500-505.

22. Regan EA, Hokanson JE, Murphy JR, Make B, Lynch DA, Beaty TH, Curran-Everett D, Silverman EK, Crapo JD: Genetic epidemiology of COPD (COPDGene) study design. COPD 2010, 7(1):32-43.

23. Hankinson JL, Odencrantz JR, Fedan KB: Spirometric reference values from a sample of the general U.S. population. Am J Respir Crit Care Med 1999, 159(1):179-187.

24. Hanania NA, Sharafkhaneh A, Celli B, Decramer M, Lystig T, Kesten S, Tashkin D: Acute bronchodilator responsiveness and health outcomes in COPD patients in the UPLIFT trial. Respir Res 2011, 12:6.

25. Tashkin DP, Celli B, Senn S, Burkhart D, Kesten S, Menjoge S, Decramer M, Uplift Study Investigators: Bronchodilator responsiveness in patients with COPD. Eur Respir J 2008, 31(4):742-750.

26. Walker PP, Calverley PM: The volumetric response to bronchodilators in stable chronic obstructive pulmonary disease. COPD 2008, 5(3):147-152.

27. Cerveri I, Pellegrino R, Dore R, Corsico A, Fulgoni P, Van De Woestijne KP, Brusasco V: Mechanisms for isolated volume response to a bronchodilator in patients with COPD. J Appl Physiol 2000, 88(6):1989-1995.

28. Anthonisen NR, Lindgren PG, Tashkin DP, Kanner RE, Scanlon PD, Connett JE, Lung Health Study Research Group: Bronchodilator response in the lung health study over 11 yrs. Eur Respir J 2005, 26(1):45-51.

29. Albert P, Agusti A, Edwards L, Tal-Singer R, Yates J, Bakke P, Celli BR, Coxson HO, Crim C, Lomas DA, Macnee W, Miller B, Rennard S, Silverman EK, Vestbo J, Wouters E, Calverley P: Bronchodilator responsiveness as a phenotypic characteristic of established chronic obstructive pulmonary disease. Thorax 2012, 67(8):701-708.

30. Nagai A, West WW, Thurlbeck WM: The national institutes of health intermittent positive-pressure breathing trial: pathology studies. II. Correlation between morphologic findings, clinical findings, and evidence of expiratory air-flow obstruction. Am Rev Respir Dis 1985, 132(5):946-953.

31. Hansen JE: Assessment of bronchoreversibility in severe emphysema. Eur Respir J 2010, 36(4):972. author reply 973.

32. Celedon JC, Speizer FE, Drazen JM, Weiss ST, Campbell EJ, Carey VJ, Reilly JJ, Ginns L, Silverman EK: Bronchodilator responsiveness and serum total lgE levels in families of probands with severe early-onset COPD. Eur Respir J 1999, 14(5):1009-1014.

33. Palmer $\sqcup$, Celedon JC, Chapman HA, Speizer FE, Weiss ST, Silverman EK: Genome-wide linkage analysis of bronchodilator responsiveness and post-bronchodilator spirometric phenotypes in chronic obstructive pulmonary disease. Hum Mol Genet 2003, 12(10):1199-1210.

34. Kim V, Pechulis RM, Abuel-Haija M, Solomides CC, Gaughan JP, Criner GJ: Small airway pathology and bronchoreversibility in advanced emphysema. COPD 2010, 7(2):93-101.

35. Han MK, Wise R, Mumford J, Sciurba F, Criner GJ, Curtis JL, Han MK, Wise R, Mumford J, Sciurba F, Criner GJ, Curtis JL, Murray S, Sternberg A, Weinman G, Kazerooni E, Fishman AP, Make B, Hoffman EA, Mosenifar Z, Martinez FJ, Nett Research Group: Prevalence and clinical correlates of bronchoreversibility in severe emphysema. Eur Respir J 2010, 35(5):1048-1056.

\section{doi:10.1186/s12931-014-0084-3}

Cite this article as: Kim et al: Airway wall thickness is increased in COPD patients with bronchodilator responsiveness. Respiratory Research 2014 15:84.

\section{Submit your next manuscript to BioMed Central and take full advantage of:}

- Convenient online submission

- Thorough peer review

- No space constraints or color figure charges

- Immediate publication on acceptance

- Inclusion in PubMed, CAS, Scopus and Google Scholar

- Research which is freely available for redistribution 